Christian Bjørnskov

\title{
How Does Social Trust Affect Economic Growth?
}

Department of Economics 


\title{
How Does Social Trust Affect Economic Growth?
}

\author{
Christian Bjørnskov*
}

\begin{abstract}
:
This paper connects two strands of the literature on social trust by estimating the effects of trust on growth through a set of potential transmission mechanisms directly. It does so by modelling the process using a three-stage least squares estimator on a sample of countries for which a full data set is available. The results indicate that trust affects schooling and the rule of law directly. These variables in turn affect the investment rate (schooling) and provide a direct effect (rule of law) on the growth rate. The paper closes with a short discussion of the relevance of the findings.
\end{abstract}

JEL Codes: O10, N40, Z13

Key words: Growth, Trust, Transmission mechanisms

\footnotetext{
* Department of Economics, Aarhus School of Business, Prismet, Silkeborgvej 2, DK-8000 Aarhus C, Denmark; E-mail: ChBj@asb.dk; Phone: +45 894861 81. I am grateful for comments from Mogens Justesen, Robert Klemmensen and participants at a conference in Çeşme.
} 


\section{Introduction}

Since the late 1980s, the term social capital has gradually become accepted as a standard phrase in the social science vocabulary. Defined by Robert Putnam (1993, p. 167) as "features of social organization, such as trust, norms, and networks, that can improve the efficiency of society by facilitating coordinated actions", the concept hit a note with both social scientists and politicians, since most people would agree that collective action is an important part of modern life and society. As such, the concept makes immediate intuitive sense and while buzz words are common phenomena in the social sciences - fancy new concepts that generate attention have come and gone for more than a century - a substantial empirical literature has confirmed that features of social capital are indeed important determinants of a number of political and economic features. Recent research nonetheless increasingly distinguishes between the constituent elements of Putnam's concept, documenting that many consequences of social capital are entirely due to the trust element, which empirical studies show forms a component that is only weakly related to the other elements of the concept (Stolle, 1998; Uslaner, 2002; Bjørnskov, 2006).

Putnam (1993) claimed that social capital could explain the growth differences across Italian regions during the post-WW2 period. Knack and Keefer's (1997) seminal paper on economic growth showed that only social trust is robustly associated with growth, and one of the most important and robust results emerging from the subsequent empirical literature is that while norms and networks are unrelated to overall economic performance, countries with high levels of trust have grown faster in recent decades than other comparable countries (Whiteley, 2000; Zak and Knack, 2001; Beugelsdijk et al., 2004). The social capital literature also implicitly points to a number of potential transmission mechanisms; one need only take a quick look to realize that trust is associated with a number of features that would appear on most economists' shortlist of important determinants of economic growth. Yet, the existing studies have not made the connection explicitly. It is therefore the purpose of this paper to connect the potential transmission channels of the trust-growth relation by estimating the influence of each channel directly. The paper is organized as follows. Based on previous literature, section 2 describes a number of potential transmission channels for social trust. Section 3 summarizes the data and the estimation strategy used in sections 4 and 5. Section 4 
briefly explores a set of background variables for social trust while section 5 estimates the growth effects of social trust through its influence on the potential transmission channels. Section 6 discusses the findings and concludes.

\section{Theoretical transmission channels}

As noted in the introduction, the social capital literature points to a set of possible transmission channels, as a number of the features that are found to be affected by social trust also emerge on most lists of determinants of economic growth. This section reviews evidence of the associations between social trust and five different potential determinants of growth, all of which have been suggested by the social capital literature. The section is in no way exhaustive of the literature but only includes the most relevant studies.

\subsection{Schooling}

First of all, in one of the original papers on social capital Coleman (1988) argued that it is a factor in creating human capital, a point later confirmed in cross-country data by la Porta et al. (1997) and in cross-state data from the US by Putnam (2001). ${ }^{1}$ The original explanation for Coleman's results was that in high-trust environments, people are more likely to help each other; i.e. high school students are more likely to access the human capital of adults within the family and neighborhood and are therefore more likely to succeed. The same would, according to this logic, be the case for fellow students who trusting that favors will in general be returned would have an incentive to give other students access to their human capital. As trust therefore so to speak squares the circle of competition versus cooperation between students, this line of thinking thus in essence provides a supply-side explanation. Trust might alternatively proxy for the strength of 'social solidarity' in a country, which could affect government expenditures on education. Given that the supply of educational possibility is affected by expenditures in the educational system, this would lead to a similar supply effect. On the other hand, demand-side explanations could be equally convincing, as firms in countries with high social trust are more likely to easily solve the agency problems inherent in any

\footnotetext{
${ }^{1}$ Coleman's study is strictly speaking not among the very first papers on social capital, that honour must probably go to David Hume and Adam Smith (Bruni and Sugden, 2000). Later, Jacobs (1961), Loury (1977) and Bourdieu (1986) have also used concepts of social capital although without the broad popularity that Coleman's study received.
} 
organization of some size. Since educated workers typically have more complex work tasks that are less easily monitored, increasing social trust is likely to generate a higher demand for education (Bjørnskov, 2005). Either way, as a first potential mechanism trust might therefore lead to growth as schooling is often found to be a significant growth factor (Barro, 1991; Temple, 2001; Weede and Kämpf, 2002).

However, the correlation between social trust and schooling could alternatively reflect the reverse causal direction. A number of studies have argued that instead of affecting schooling, trust is itself created in the schooling system as a result of socialization to common norms, through demonstration effects arising from teachers sanctioning trusting and cooperative behaviour, and effects arising from the fact that children are given information and mental tools that enables them to better interpret and asses the actions of others (Knack and Keefer, 1997; Glaeser et al., 2000; Gradstein and Justman, 2000; Knack and Zak, 2002). Given this direction of causality, part of the effect of trust on growth might be spurious due to the correlation with schooling. Considerable care is therefore needed in order to sort out the causal direction.

\subsection{Governance}

A second potential mechanism derives from Putnam's (1993) original work. In the book that popularized the concept and a later article by Helliwell and Putnam (1995), he argues that differences in social capital have led to the observed differences in the quality of governance across Italian regions. Multiple mechanisms can theoretically lead to this effect. Knack (2002), who finds evidence of the relation in cross-state US data, stresses demand-side explanations by pointing out three different mechanisms through which trust could affect governance. Firstly, high trust could lead to higher accountability, as decisions have to be responsive to the preferences of the populace. This argument is along the lines of Putnam's original thoughts in which he stresses the association between trust and 'civicness', arguing that more civic citizens are better at holding politicians accountable and politicians therefore "are more inclined to temper their worst impulses rather than force public protests" (Putnam, 2000, p. 346). Secondly, consensus or agreement is least likely when political positions are polarized. However, even in countries in which the positions of politicians and voters are strongly polarized, those with high trust are likely to experience more situations in which 
consensus is reached, as both adversely affected voters and politicians have more trust that they will be compensated in future decisions for any cost imposed on them through current policy decisions. In such situations, sufficient trust thus helps politicians and voters surmount a prisoners' dilemma-like problem associated with intertemporal logrolling, which lowers the risk of myopic policy-making. ${ }^{2}$ Thirdly, Knack (2002) finds that US states with high trust are more likely to introduce policy innovations, possibly because trustworthy politicians are better at credibly signaling their necessity and thus avoiding popular skepticism to apparently obscure institutional changes. Conversely, in low-trust societies voters will be more inclined to interpret policy innovations as concessions to special interests that may bias policy choices, thereby making any innovation less likely to receive the necessary public support.

Nobel laureate Kenneth Arrow (1972), on the other hand, hinted at what is basically a supply-side explanation for the trust-governance association by remarking that "the system [of judges and police] would itself disappear if on each occasion they were to sell their services and decisions [...] To the extent that it is incomplete, it must be supplemented by an implicit or explicit social contract. Thus one might loosely say that the categorical imperative and the price system are essential complements" (Arrow, 1972, p.357). In his view, officials in high-trust countries are therefore more likely to honor the social contract that all societies implicitly rest upon. The logical consequence is that more social trust leads to a higher supply of quality decisions in the bureaucracy and the political process and hence better governance, which is also consistent with the observable negative association between trust and corruption (Uslaner, 2002). Both demand and supply mechanisms therefore lead to the consequence that trust is associated with the quality of policy-making, which is mostly found to be an important determinant of growth. ${ }^{3}$

The overall implication has received strong empirical support. The first empirical studies confirming that social trust leads to improved governance occurred in Putnam (1993), and the result has since been replicated in both US state data and cross-country

\footnotetext{
${ }^{2}$ This might also imply that high-trust countries can sustain a wider representation of diverse political parties in the political process without risking that this diversity leads to political instability.

${ }^{3}$ While earlier empirical studies may have questioned the association between governance or institutional quality and growth, more recent research seems to concentrate on the question of how 'deep' a determinant governance is (e.g. Dollar and Kraay, 2003; Rodrik et al., 2004).
} 
analysis (la Porta et al., 1997; Rice and Sumberg, 1997; Knack, 2002). The original paper by Knack and Keefer (1997) suggests that trust can be created by formal institutions such as a strong rule of law, a lead taken up by. Zak and Knack (2001, p. 316) who also suggest the reverse causal direction by stating that their results "strongly support [...] that formal institutions and social homogeneity increase growth in part by building trust”. Paraphrasing the Danish philosopher Søren Kierkegaard, the rule of law in this line of thinking shortens 'the leap of faith' inherent in any act of trust and therefore makes trust more likely. Rothstein (2003) alternatively surmise that when individuals observe corrupt behavior in public institutions, they infer from that observation that people in general are not to be trusted. Hence, institutional quality and non-corrupt behavior in his view leads to higher trust, a direction of causality that receives empirical support in Knack and Zak (2002) and Berggren and Jordahl (in press), positing that proper legal protection induces people to be more likely to trust. In total, which direction causality runs remains an open question that, like in the case of schooling, makes the choice of an appropriate estimation procedure important. Yet, one way or the other social trust might be correlated with growth through its association with governance, which most studies find to be an important growth factor (Kormendi and Meguire, 1985; Knack and Keefer, 1995; Berggren, 2003; Dollar and Kraay, 2003; Rodrik et al., 2004).

\subsection{Investments}

As a third possibility, Arrow (1972, p. 357) noted that "virtually every commercial transaction has within itself an element of trust, certainly any transaction conducted over a period of time". As investments are undertaken in order to maximize the number and size of such transactions in the future, it could well be expected that social trust affects the investment rate either directly or through increasing intra-country trade and economic activity. Pointing to yet another potential growth factor, Zak and Knack (2001) take this lead by arguing that trust leads to increased investments through a theoretical direct effect in which investment brokers are intermediaries between investors and firms. In the model, the lack of trustworthiness of these brokers incurs upon society a transaction cost associated with investments, which lowers the investment rate. The authors subsequently find support in data from 51 countries. By 
affecting investments, trust might therefore lead to growth as the investment rate is one of the most important growth factors (Barro, 1991; Levine and Renelt, 1992; Wazciarg, 2001).

A related hypothesis is that investment prices are affected by social trust having a governance-like effect on investment policy, possibly since more civic-minded politicians in the vein of Putnam's arguments are more likely to balance diverse interests, or that increased transparency of government actions reduces risks due to political instability and thus also reduces the costs of investments. In a contribution predating the social capital concept, Niklas Luhman (1979) made the additional point that trust reduces the complexity of modern society, which could as a possible implication have that the span of contingencies to consider with any economic transaction or activity is reduced. Social trust may therefore also work as a risk-reducing factor per se that e.g. leads to higher investment rates or lowers the price of investments by making society more stable and predictable, which would lower transaction costs and enable firms to undertake longer-term commitments.

\subsection{International trade}

Fourthly, Greif $(1989,1994)$ uses historical examples of trade across the Mediterranean in Medieval times and de Groot et al. (2004) employ current bilateral trade patterns to demonstrate that trust might influence the extent and direction of trade by providing better security of the gains of trade. Both studies stress the influence of trust on transaction costs as having trustworthy partners abroad lowers the risks of noncompliance with trade contracts and therefore lower transaction costs. De Groot et al. (2004), following Anderson and Marcouiller (2002), also mention that the quality of formal institutions could have a similar effect. However, they find that most of the trust effect on the direction of trade arises directly and only a minor part is due to an indirect effect through governance. Social trust might also via this mechanism be connected to investments and growth by allowing countries to trade more extensively with foreign partners. 


\subsection{Government}

Finally, a number of authors connect social trust to the size and structure of the government sector by observing that the Nordic countries have both highly trusting populations and extensive welfare states. Rothstein (2003) and Kumlin and Rothstein (2004) suggest that trust is associated with the supply of universal welfare goods while means-tested welfare is bad for trust, based on the explanation that means-testing stigmatizes the poor while excluding citizens slightly better off from welfare goods. This, they argue, creates social cleavages and a sense of unequal access to public goods, which reduces social trust. Svendsen (2004), on the other hand, makes the opposite point by arguing that high-trust countries have been better able to maintain extensive welfare states precisely because the high trust levels to some degree have insulated these nations from adverse behavior and moral hazard. The provision of universal welfare extended to a large part of the population incurs significant monitoring and enforcement costs to ensure that only those eligible to different welfare benefits actually receive them. Svendsen (2004) argues that in high-trust countries, a substantial part of the population does not need monitoring as they are likely to behave in an honest manner, thereby lowering the transaction costs of supplying public welfare goods. As such, this argument may go some way in explaining why the Nordic countries apparently can support welfare systems without surrendering to costs that would destroy the system from within in less trusting countries. Some level of social trust might therefore be necessary to sustain a large government sector.

However, it is important to stress that a variety of indirect mechanisms could also lead to either of these five outcomes. Good governance might for example be associated with better investment policy or social and political stability, both of which would reduce transaction costs. Governance might alternatively secure more productive investments as firms would be insulated from some of the political risks and would therefore be more inclined to undertake more economically risky endeavors. As another indirect mechanism, social trust could influence the investment rate through its potential effect on schooling, since human capital theoretically might be a complement to physical capital (e.g. Nelson and Phelps, 1966; Romer, 1990; Topel, 1999). Likewise, if social trust affects the extent of trade an indirect mechanism through the investment rate might affect growth (e.g. Levine and Renelt, 1992; Wazciarg, 2001). Conversely, a 
large welfare state necessarily involves a substantial government expenditure, which may weaken incentives and crowd out investments, thereby leading to lower growth (Barro, 1991). In the following, it is hence necessary to take potential indirect effects into account.

In summary, a number of studies have connected social trust to potential determinants of economic growth. The above mini survey of the literature leaves us with at least five different mechanisms linking trust to growth to explore in the following: 1) schooling; 2) governance; 3) a direct investment link; 4) investment prices; and 5) government expenditures. The next section describes the data used for measuring effects through these mechanisms.

\section{Data and estimation strategy}

First of all, I use what has become the standard trust indicator, which is the proportion of a population that answers yes to the question: "In general, do you think that most people can be trusted, or can't you be too careful?" This question has been asked in a number of countries by the World Values Survey (WVS) since 1981 and is usually found to be a good indicator of what it is intended to measure. ${ }^{4}$ As a number of studies all find that the trust scores are stationary over time (Volken, 2002; Bjørnskov, 2005), the variable used in the following is the average of all available observations from each country. The stability of the trust measures hence implies that panel data estimates do not make much sense as most of the variation over time is likely to be random. I supplement the WVS data with recent trust scores from the Danish Social Capital Project that asks the exact WVS question, and the Latinobarometro, which has asked a very similar question. The trust scores on the full sample of 86 countries are listed in the appendix. The sample used in the following is substantially reduced due to data availability while Iran and China are dropped as both countries are outliers in most respects (Uslaner, 2002; Bjørnskov, 2005).

Some authors have questioned the validity of the use of surveys in economics, and in particular the use of the social trust measure. For example, the November 2002 issue of The Economic Journal was devoted to social capital research, including the question

\footnotetext{
${ }^{4}$ The most recent data derive from Inglehart et al. (2004) while trust scores from earlier waves of the WVS can be downloaded on the homepage. The Latinobarometro data can be accessed at http://www.latinobarometro.com while the Danish data are available from the author.
} 
of how to use various social capital measures in economic research. Yet, part of the confusion seems to derive from the often rather indiscriminate use of the term 'social capital'. As Bjørnskov (2006) shows that Putnam's concept at the macroeconomic level consists of three orthogonal factors, this confusion can be avoided by using social trust instead of one of the many measures proposed in the literature that all tend to pool elements of these orthogonal factors. Moreover, national social trust scores have proved to be a fairly valid measure of honesty, trust and trustworthiness. For example, Knack (2001) shows that the scores correlate heavily with the share of wallets returned in wallet drop experiments from capitals around the world. Uslaner (2002) also shows that social trust is strongly associated with a number of other outcomes such as corruption and violent crime that one would a priori require of any valid measure.

Turning to the potential transmission channels, education or human capital has proved to be difficult to measure and the theoretically strong association with economic growth therefore often finds surprisingly weak empirical support (e.g. Lorgelly and Owen, 1999; Pritchett, 2001; Temple, 2001). A major problem in this respect is that most existing indicators only measure the quantity of schooling; studies using these indicators thereby implicitly come to assume that the quality of schooling is equal across countries and time. What is more, while primary education could arguably be of paramount importance to developing countries, most rich countries have mandatory primary schooling requirements, and endogenous growth models based on technological change more relevant to developed countries suggest an influence of higher education instead of basic skills (e.g. Nelson and Phelps, 1966; Romer, 1990). In order to measure human capital in a sufficiently precise and parsimonious way, the present schooling indicator is therefore the result of performing a principal components analysis with three different measures of education: 1) the average intelligence quotient from Lynn and Vanhanen (2002), used as a measure of the quality of human capital, as it provides a proxy for the average analytical skills of the population; 2) the gross enrollment rate in secondary school from World Bank (2004); and 3) the average schooling length of individuals over the age of 25 from Barro and Lee (2001). These three variables load 
strongly onto the same principal component, and the variable used in the following consequently consists of the factor scores from this analysis. ${ }^{5}$

The data on governance derive from the Kaufmann et al. (2003) dataset from which I primarily use the 'rule of law' index as this fits the standard theoretical considerations closest. These data result from principal components analyses with a large number of primary indices; they are controlled for various spurious influences and are therefore often considered the first choice of indicators of governance due to the meticulous care with which they are constructed. In an alternative set of regressions I use either an average of all six Kaufmann indices as statistical separation of these indices have proven rather difficult, an index of government effectiveness from the same source, or an index of legal quality from the economic freedom indices published by the Fraser Institute (Gwartney and Lawson, 2002). ${ }^{6}$

The initial 1970 GDP per capita in purchasing-power adjusted international dollars as well as a number of other variables derive from the Penn World Tables (Heston et al., 2002). This also includes the 30 -year averages of investment rates ( $\%$ of GDP), government expenditures (\% of GDP), openness (trade volume, \% of GDP) and price distortions. The latter variable is the ratio of investment prices to the general price level, which arguably reflects the quality of investments and investment policy of a given country since both productivity and less distortionary policies are likely to result in lower relative investment prices, which works here as an outcome measure of investment policy. Government expenditure serves as a proxy for the size of the welfare state and thus allows exploring the set of particular transmission channels associated with welfare state effects.

Growth is measured in the standard Barro-type way as the difference between the logs to GDP in 2000 and 1970, divided by 30. As a background variable for schooling, I also use the average fertility (births per woman), taken from World Bank (2004), as

\footnotetext{
${ }^{5}$ The loadings in the principal components analysis are .89 (IQ), .89 (secondary schooling) and .91 (schooling length) yielding one component with an eigenvalue of 2.42 explaining 81 percent of the variation. It should be stressed that I remain agnostic with respect to the question whether the IQ scores reflect genetic variation or simply a combination of the quantity and quality of schooling in different countries as both would affect schooling, the first through underlying any human capital investment, the second by making IQ scores a rough measure of schooling quality.

${ }^{6}$ The correlations across the six Kaufmann et al. indices are all in the vicinity of .8. Bjørnskov (2006) therefore employs principal components analysis to form an overall governance index, which preserves more than $90 \%$ of the variation in the six indices.
} 
family size arguably might influence education decisions in income or credit constrained families (e.g. Becker and Lewis, 1973). Finally, I employ a standard set of background variables of trust (see e.g. Knack and Zak, 2002; Uslaner, 2002; Bjørnskov, 2005). The set includes income inequality measured by Gini coefficients deriving from the Deininger and Squire (1996) dataset, data on monarchies and the religious composition of the population from CIA (2004) supplemented by USDS (2004), and ethnic diversity, measured as the probability that two random citizens of a country do not share ethnicity, taken from Alesina et al. (2003). All data are summarized in Table 1.

\section{INSERT TABLE 1 ABOUT HERE}

A first indication of where to search for effects of social trust is provided in Table 2, which reports the simple and partial correlations between trust and variables capturing a number of potential transmission channels. It is apparent in the table that although the simple correlations with all but openness are large, the partial correlations when controlling for GDP per capita in 1970 show somewhat different results. Openness, the price distortion and government expenditures are far from being significantly correlated with social trust; the latter even has the 'wrong' sign. The partial correlations for schooling, rule of law, the alternative governance indicators, and the investment rate remain significant and in the former four cases also of substantial size. However, whether these correlations reflect causal influences and in which directions these influences work must be subject to further scrutiny in the two following sections in which all but one variable are analyzed. The exception is openness, which not even has a simple correlation with social trust and is hence excluded from the list of potential transmission mechanisms. ${ }^{7}$

\section{INSERT TABLE 2 ABOUT HERE}

\footnotetext{
${ }^{7}$ It should be noted that while the extent of trade does not seem to be affected by social trust, the direction of trade - i.e. the choice of trading partners - may still to some degree depend on trust (den Butter and Mosch, 2003; de Groot et al., 2004).
} 
To sort out the causal influences - if at all possible with cross-sectional data - I use two- and three-stage least squares regression. The two-stage least squares regressions (2SLS) are naturally used to inform about the causality between social trust and the potential transmission mechanisms while Zelner and Theil's (1962) three-stage regression procedure (3SLS) is utilized as a way to trace the effects of trust through the transmission mechanisms to economic growth. Results are reported in a series of tables in which the bottom panels report sample size, pseudo R squared, either F- or Chistatistics and the root mean square error (RMSE). In connection with 2SLS results I also report Sargan's test for overidentification, which is often used as a test of exogeneity of instrumental variables given that at least one of the instruments is truly exogenous. This is certainly the case since the religious composition of populations has been fairly stable for very long periods of time, and historical variables such as having a monarchy or a communist past cannot be changed.

To render it probable that the findings are not spurious, I perform two types of robustness tests. All regressions in section 5 are run on three different samples. The full sample naturally consists of all countries for which a full data set is available while the reduced sample consists of the full sample minus the tails of the trust distribution; i.e., countries with trust levels above $60 \%$ or below $10 \%$. The countries excluded in the reduced sample are Denmark, Norway and Sweden (high-trust countries), and Brazil, Costa Rica, Ecuador, Peru, the Philippines, Tanzania and Uganda (low-trust countries). A third sample determined by the regression using the full sample consists of excluding the observations with the largest absolute residuals in each case such that the sample size employed is the same as in the reduced sample. ${ }^{8}$ The second robustness test consists in re-estimating the relations using alternative indicators for schooling and governance to test for the possibility that effects are specific to a single indicator; the results of these tests are reported in an appendix. I do not control for robustness to the empirical specification or specific omitted variables; interested readers are instead referred to Beugelsdijk et al. (2004) and Bengtsson et al. (2005), both of which demonstrate that the growth effects of social trust are fairly robust in that sense.

\footnotetext{
${ }^{8}$ Instead of excluding observations with residuals that are large in an absolute sense, I use this approach since the sample sizes can otherwise get rather small in some cases due to the relatively large standard errors generated by the 3SLS estimator.
} 


\section{Determinants of social trust}

This section only briefly explores the determinants of social trust, as it repeats the basic findings in Uslaner (2002) and Bjørnskov (2005). The main purpose of this exercise is to test for the reverse causality suggested by some of the social capital literature. The results reported in Table 3 first of all show that income equality is one of the primary determinants of social trust - as Uslaner (2002) stresses, it is not the level but the distribution of income that matters. GDP per capita is therefore not included as it is entirely unrelated to trust. The table also provides confirmation of the finding that monarchies have higher trust levels, as do countries with substantial Protestant populations while Muslim populations tend in the other direction and postcommunist countries have trust deficits, all other things being equal. On the other hand, contrary to previous literature ethnic diversity is not significantly associated with social trust in this sample of countries. Although the coefficient is always negative and of roughly the same size throughout a variety of different specifications (not shown), its significance appears to depend highly on which countries are included. Clearly, although this question must await future research there is need for more work on the circumstances under which diversity can lead to lower trust.

\section{INSERT TABLE 3 ABOUT HERE}

Turning to one of the main purposes of this paper - the causality of the potential transmission mechanisms to growth - the 2SLS estimates in the table reject that there are any effects of schooling, rule of law or government expenditure (proxying for welfare effects) on social trust. As such, a more careful control for reverse causality leads to a rejection of results in a number of earlier studies that implied a more optimistic assessment of the potential of policy-induced effects on social trust (Knack and Keefer, 1997; Zak and Knack, 2001; Knack and Zak, 2002). It should be noted that the insignificance is not a result of weak instruments, as the F-statistic in the first-stage regression with rule of law is 70.41 , with governance 69.47 and with legal quality 23.81; the instruments therefore easily pass both Staiger and Stock's rule of thumb and the Sargan tests. Although a number of studies have argued for an effect of these features the findings here are therefore consistent with those studies relying on more 
than simple OLS estimates. As reverse causality thus does not seem to be a problem, I move on to the main topic after this intermezzo. The variables included in the specification in column 3 of Table 3, which employs the full sample used in the growth regressions in the following, are used as instruments for social trust in the next section.

\section{Economic consequences of social trust}

As section 4 documents, the direction of causality must necessarily run from social trust to a set of variables capturing potential transmission mechanisms if the correlations in Table 2 are not spurious. These mechanisms eventually connect trust to growth either directly or through the investment rate.

\subsection{Direct consequences of social trust}

Table 4 firstly looks at the direct consequences of social trust on schooling and the rule of law, both estimated by 2SLS. Beginning with the former, the results clearly support that trust is a determinant of schooling alongside fertility and the initial GDP per capita, a set of findings that proves robust to being estimated in any of the three samples and explains the bulk of the variation in the data. As schooling seems to be affected by social trust but does not affect trust, the evidence thereby confirms the findings of previous studies showing that higher levels of social trust lead to higher levels of schooling (e.g. la Porta et al., 1997; Putnam, 2000; Bjørnskov, 2005). The effect is robust to changes in the sample although the exclusion of outliers generates a large and less significant coefficient. On the other hand, the findings in the previous section suggest that there is no effect in the opposite direction. In total, the findings here therefore contradict the conclusions reached in previous studies using simple OLS that schooling can create trust.

The second significant effect to be found in these data is that of social trust on the rule of law, which turns out to be strongly positive and thus confirms previous findings (e.g. Putnam, 1993; Knack, 2002; Uslaner, 2002). Once again, the specification does a good job explaining the variation. However, as the findings in Table 3 rejected that the rule of law affects trust but those in Table 4 confirm the opposite direction of causality, the evidence firmly rejects the conjecture in e.g. Zak and Knack (2001) and Berggren and Jordahl (in press) that formal institutions can create social trust. The causal effect 
from trust to the rule of law is moreover robust to changes in the sample although the coefficient in the sample without potential outliers is somewhat smaller than in either of the other samples. In addition, the findings also reconfirm the well-known positive effects of income and on the rule of law as well as confirming that openness to trade has a positive effect, cf. Rodrik et al. (2004).

\section{INSERT TABLE 4 ABOUT HERE}

These findings could still be indicator-specific, a point explored in the corresponding appendix Table A.4. The table presents the findings with alternative indicators, showing that two out of three schooling indicators are significantly affected by social trust. In the last, the effect on the IQ of social trust is not significant, which may nonetheless be an artifact of the way Lynn and Vanhanen (2002) treat missing observations. ${ }^{9}$ The effect of trust on governance is also quite robust, as the coefficient in regressions with all three alternative indicators remains significant and of approximately the same size. Any influence of trust on the remaining potential transmission channels is nonetheless rejected; results are reported in Table 5. Government expenditure is negatively related to income but there is no effect of social trust. Neither is there a direct influence of trust on the investment price distortion, which is only significantly related to initial GDP per capita. $^{10}$

\section{INSERT TABLE 5 ABOUT HERE}

\footnotetext{
${ }^{9}$ Lynn and Vanhanen's (2002) chosen procedure for estimating IQ in countries without a national survey consists in taking the average of IQ in neighbouring countries with roughly the same ethnic composition. This procedure therefore induces an artificial intraregional similarity that makes identification of an effect of trust rather difficult in the presence of regional fixed effects. Without such effects, trust becomes significant at $\mathrm{p}<.10$ with a coefficient of .088, implying that a one standard deviation shock to trust would result in an increase in IQ of $15 \%$ of a standard deviation.

${ }^{10}$ Any potential influence from trust on government expenditures turns out to be spurious since ethnic diversity (not shown) is negatively related to government expenditure (cf. Alesina et al., 2003). Tests also reject that trust has an indirect effect on the investment policy variable. Given the lack of other determinants, one might well take this is evidence that there is a strong element of investment policy in this variable as it is supposed to measure.
} 


\subsection{Effects on investments and growth}

Noting that schooling and the rule of law but not other variables are directly affected by social trust, the next step in the analysis is to trace these effects through the economy. In particular, the effects could either directly influence the growth rate or indirectly through the investment rate. The results presented in Table 6 are therefore estimated by 3SLS. When firstly turning to the determinants of the investment rate, openness leads to more investments as is standard, although this effect is only significant at $\mathrm{p}<.10$ in the reduced sample. The logarithm to initial income per capita is significantly negatively related to the investment rate, which the investment price distortion quite naturally also is. However, when interpreting the large negative effect of income it should be held in mind that both investment policy (price distortions) and schooling is positively associated with income. Calculating the cumulative effect of initial income, this becomes virtually zero since both schooling and the investment price distortion are strongly positively associated with the investment rate. Initial income is to a large extent the result of amassed past investments; hence the negative effect of initial income simply indicates that there are decreasing returns to scale of investments, all other things being equal. Conversely, neither the rule of law nor the alternative governance indicators tested in appendix Table A.3 are associated with the investment rate. It follows that social trust exerts an influence on the investment rate, but not directly as suggested by Zak and Knack (2001). Rather, it is the influence on schooling that makes production more efficient and therefore prompts more investments by increasing the productivity of such investments. Since the inclusion of a direct effect of social trust in the regressions always produces insignificant coefficients with t-statistics well below one, it seems safe to conclude that the investment effects of trust through schooling are exhaustive. Moreover, the simple robustness tests reported in Table A.3 in the appendix replicate the investment results with the three alternative governance indicators in order to test whether the findings are particular to the choice of the rule of law index. The results are nearly identical across the columns and they are therefore not particular to any single measure of governance.

\section{INSERT TABLE 6 ABOUT HERE}


The final step is to trace the effects to economic growth, as is done in the three right hand side columns in Table 6, that again report 3SLS estimates. The results for one thing reproduce three standard findings: 1) a strong conditional convergence effect; 2) a growth effect of investments; and 3) an effect of the rule of law. The implications are nevertheless slightly different than is standard. Firstly, the results show that the growth effects of schooling work through the investment channel, which in itself is a new finding. As for example Topel (1999) calls for more evidence of how schooling transmits to growth while documenting that schooling increases labor productivity, the findings presented in Table 6 support the notion that human capital is a complement to investments in physical capital. In other words, the effects of schooling are consistent with a theoretical explanation stating that it leads to an increase in the rate of innovations or technological diffusion (e.g. Nelson and Phelps, 1966; Romer, 1990). Since social trust is a strong determinant of schooling, the results provide confirmation of one of the potential transmission mechanisms as suggested by Zak and Knack (2001) although with the difference that the trust effect is indirect.

Secondly, there is an additional effect of social trust running through the governance channel, which is more direct. The rule of law does not affect investments or investment prices, but provides a direct effect that can be interpreted as causing an increase in total factor productivity. Although this result contrasts the well-known findings in Mauro (1995), it is consistent with more recent studies by e.g. Hall and Jones (1999) and Méon and Weill (2005) who suggest that governance leads to higher aggregate productivity, not necessarily a higher investment rate. The same conclusions apply to the three other governance measures reported in appendix Table A.3. Finally, it should be noted that entering social trust in the investment and growth equations in any of these systems proved to generate coefficients far from significance; the effects running through schooling and governance thus seem exhaustive of the full effect of trust.

In total, the findings suggest that social trust translates into economic growth through two main channels: raising the schooling level and improving governance. Table 7 below summarizes the transmission channels and the size of the effects. Raising the trust level of an average country from the global average to approximately the level of North America - a change corresponding to a one standard deviation shock to social 
trust - results in an increase of roughly one percentage point in the growth rate of GDP ( $60 \%$ of a standard deviation) through the two channels outlined above, all other things being equal. The contributions to growth of such a shock through the transmission mechanisms in the full sample are $26 \%$ and $34 \%$ (of a standard deviation) from schooling and rule of law, respectively; $16 \%$ and $26 \%$ in the reduced sample; and $32 \%$ and $31 \%$ in the sample without outliers, although it should be noted that the explanatory power of the specification is reduced when using the latter sample. No result is indicator-specific and the only real difference between the three sets of results pertaining to the different samples is that excluding outliers shifts the balance of importance towards the schooling channel.

\section{INSERT TABLE 7 ABOUT HERE}

Although the samples are larger, the total effect of social trust on economic growth in the full sample and samples without outliers therefore approximately corresponds to that found by previous studies. For example, the results in Zak and Knack (2001) indicate that a one standard deviation shock to social trust generates an increase in the growth rate of about $60 \%$ of a standard deviation, i.e. an identical effect, while the estimate in Whiteley (2000) based on a slightly different trust indicator is somewhat larger. Beugelsdijk et al. (2004), exposing the trust-growth association to various robustness exercises, find effects of a one standard deviation shock ranging from 1.05 percentage points, corresponding to about two-thirds of a standard deviation, to a lower bound of .65 percentage points. The present results may therefore range in the upper region of a natural confidence interval although it must be stressed that they are subject to considerable uncertainty, not least because of the chosen estimation procedure. The effect using estimates without outliers is virtually identical to the one obtained in the full sample while the reduced sample generates a somewhat smaller effect. When instead using the lowest estimates throughout irrespective of which sample they derive from one gets a cumulative effect of a one standard deviation shock to trust of .57 percentage points, corresponding to $35 \%$ of a standard deviation of which roughly half derives from each channel. This is fairly close to the relatively low estimate obtained in the robustness exercises in Bengtsson et al. (2005) and to the lower bound in 
Beugelsdijk et al. (2004), and may thus be indicative of the importance of observations in the tails of the trust distribution. ${ }^{11}$ However, it seems safe to conclude that the effects of trust are due to neither coincidental problems in countries with the lowest trust scores nor any specific Scandinavian excellence or other outlier influences. Although the estimates of the total effect are surrounded by a large confidence interval, the findings remain significant throughout and therefore warrant some discussion.

\section{Discussion and conclusions}

A number of studies in the economic growth literature have in recent years found social trust to be an important and robust determinant of economic growth. Starting with Knack and Keefer's (1997) ground-breaking work, most studies have implicitly offered a set of different explanations for the result although none have dealt explicitly with the inherent causality issues. The purpose of this paper has been to explore the transmission channels through which social trust affects economic growth, taking these problems into account. Although an array of possibilities has been brought forward in the social capital literature, the findings in this paper suggest that trust has identifiable effects through two channels only: schooling and governance. Contrary to previous suggestions in the social capital literature and given that instrumental variables can inform about causality in cross-sectional analysis, the findings support that causality runs from social trust to schooling and governance, not the other way. Trust therefore appears to be a deeper determinant of economic development than any of these variables, a claim lent more intuitive validity by noting that growth rates have fluctuated and both schooling and the rule of law in general have improved in the 30 -year period in question. Meanwhile, the social trust scores obtained from international surveys have been remarkably stable over time, which is difficult to reconcile with the idea that schooling or governance should have caused the present levels of social trust (Uslaner, 2002; Volken, 2002; Bjørnskov, 2005).

\footnotetext{
${ }^{11}$ It should be noted that when doing the opposite, i.e. calculating the total effect of trust on growth by using the largest estimates, the effect of a one standard deviation shock is 1.31 percentage points, or $80 \%$ of a standard deviation. Note also that Bengtsson et al. (2005) includes a measure of schooling in their baseline specification and thus induces a downwards bias in all estimates. When adjusting for this bias, relying on the estimated effect of schooling in the present paper, their imputed average estimate is fairly close to the estimated effect of governance in this paper.
} 
However, two questions remain unresolved. Firstly, everything might still be endogenous in the very long run. The possibility for example exists that a strong rule of law could protect existing trust from deteriorating when society is hit by an adverse shock, i.e. the existence of a fair legal system could work to contain societal developments that in countries with weaker systems may cause a decrease in trust. A potential case in point could be the postcommunist transition in which the already low trust levels seem to have deteriorated in some countries as the organization of society was radically changed while the legal systems failed to provide much protection for ordinary citizens in most of these countries. Likewise, a strong educational system could potentially work to perpetuate both high and low levels of social trust much in the same way as Bourdieu (1986) argued that the French schooling system reproduces the existing social structure. This would, however, not imply that a weak educational system is beneficial to the development of social trust but only that the system in lowtrust countries probably should focus on communicating measurable skills that might increase social mobility and not democratic norms or other 'soft' skills that could perpetuate existing inequalities.

Secondly, it must be stressed that for now it is unknown whether the effects of social trust on schooling and governance arise mainly due to what can be thought of as either demand or supply effects. The standard theories in the social capital literature explain the effect of trust on schooling as a supply reaction due to students gaining easy access to the human capital of other people in high-trust societies. Yet, an equally probable explanation could rest on firms' demand for educated labor due to lower costs associated with monitoring workers with complex work tasks in high-trust countries. On the other hand, effects of social trust on governance have traditionally been explained as effects of higher demand for good governance from high-trust voters. Relying on arguments first proposed by Arrow (1972), higher trust might also lead to improved governance by increasing the supply of honest bureaucrats and politicians who will be likely to make unbiased policy choices. Which mechanisms dominate remains an open question.

The final step in the paper has been to make the connection to economic growth. The empirical results support that schooling positively affects the investment rate, which is not standard but could be expected given Topel's (1999) finding that schooling 
improves labor productivity. By affecting the returns to input factors positively, improved schooling leads to an increased investment rate, which in turn - as is standard - leads to a higher growth rate. Governance, on the other hand, is not associated with the investment rate but affects economic growth directly, probably due to its effects on overall transaction costs and therefore on the growth of total factor productivity. As social trust affects both these variables, the estimates provide evidence that the transmission mechanisms through which trust affects growth are schooling and governance. Moreover, these mechanisms seem exhaustive of the effects.

Overall, the present paper provides evidence that social trust is a deep determinant of economic development by affecting the quality of governance and schooling. These findings should, however, not be taken to imply that the distribution of economic success or failure in the world is culturally predetermined. Consistent with the estimates presented here, trade policy also has an effect through both an investment channel and a governance channel although trade volume is not associated with social trust.

Furthermore, economic history clearly shows that there are different paths to wealth and any explanation relying only on the effects of cultural features stable over time would contradict the obvious existence of convergence mechanisms. For example, social trust in France - one of the world's richest countries - is somewhat below the global average, and fast developers like Malaysia and Singapore also score low on the index. Having a high degree of social trust in society nonetheless seems to make beneficial institutional and educational development more likely. To the extent that countries do not enjoy that advantage, the importance of other policy measures simply becomes even more crucial to economic development.

\section{Appendix}

INSERT TABLE A.1 ABOUT HERE

INSERT TABLE A.2 ABOUT HERE

INSERT TABLE A.3 ABOUT HERE 


\section{References}

Alesina, A., A. Devleeschauwer, W. Easterly, S. Kurlat, and R. Wazciarg. (2003). "Fractionalization," Journal of Economic Growth 8, 155-194.

Anderson, J.E., and D. Marcouiller. (2002). "Insecurity and the Pattern of Trade: An Empirical Investigation,” Review of Economics and Statistics 84, 342-352.

Arrow, K.J. (1972). “Gifts and Exchanges,” Philosophy and Public Affairs 1, 343-367.

Barro, R.J. (1991). "Economic Growth in a Cross-Section of Countries," Quarterly Journal of Economics 106, 407-443.

Barro, R.J., and J-W. Lee. (2001). "International Data on Educational Attainment: Updates and Implications," Oxford Economic Papers 53, 541-63.

Becker, G.S., and H.G. Lewis. (1973). "On the Interaction Between the Quantity and Quality of Children,” Journal of Political Economy 81, S279-288.

Bengtsson, M., N. Berggren, and H. Jordahl. (2005). "Trust and Growth in the 1990s: A Robustness Analysis”, Working Paper no. 60, the Ratio Institute.

Berggren, N. (2003). "The Benefits of Economic Freedom: A Survey," The Independent Review 8, 193-211.

Berggren, N., and H. Jordahl. (in press). "Free to Trust? Economic Freedom and Social Capital," Forthcoming in Kyklos.

Beugelsdijk, S., H.L.F. de Groot, and A.B.T.M. van Schaik. (2004). "Trust and Economic Growth: A Robustness Analysis. Oxford Economic Papers 56, 118-134. Bjørnskov, C. (2005). Investigations in the Economics of Social Capital. PhD thesis, Aarhus School of Business.

Bjørnskov, C. (2006). “The Multiple Facets of Social Capital,” European Journal of Political Economy 22, 22-40.

Bourdieu, P. (1986). “The Forms of Capital.” In John G. Richardson (ed), Handbook of Theory and Research for the Sociology of Education. New York: Greenwood Press. Bruni, L., and R. Sugden. (2000). "Moral Canals: Trust and Social Capital in the Work of Hume, Smith and Genovesi," Economics and Philosophy 16, 21-45.

CIA. (2004). The CIA World Factbook 2004. Washington, DC: Central Intelligence Agency.

Coleman, J.S. (1988). "Social Capital in the Creation of Human Capital," American Journal of Sociology 94, S95-S120. 
Deininger, K., and L. Squire. (1996). “A New Data Set Measuring Income Inequality,” World Bank Economic Review 10, 565-569.

Den Butter, F.A.G., and R. Mosch. (2003). "Trade, Trust and Transaction Cost," Tinbergen Institute Discussion Paper 03-082/3.

De Groot, H.L.F., G-J. Linders, P. Rietveld, and U. Subramanian. (2004). “The Institutional Determinants of Bilateral Trade Patterns,” Kyklos 57, 103-123.

Dollar, D., and A. Kraay. (2003). "Institutions, Trade, and Growth," Journal of Monetary Economics 50, 133-162.

Durlauf, S. (2002). "On the Empirics of Social Capital,” The Economic Journal 112, 459-479.

Greif, A. (1989). "Reputation and Coalitions in Medieval Trade. Evidence on the Maghribi Traders," Journal of Economic History 49, 857-882.

Greif, A. (1994). "On the Political Foundations of the Late Medieval Commercial Revolution. Genoa during the Twelfth and Thirteenth Centuries," Journal of Economic History 54, 271-287.

Gwartney, J., and R. Lawson. (2002). Economic Freedom of the World: 2002 Annual Report. Vancouver: Fraser Institute.

Hall, R., and C. I. Jones. (1999). "Why Do Some Countries Produce So Much More Output per Worker than Others?” Quarterly Journal of Economics 114, 83-116. Helliwell, J.F., and R. Putnam. (1995). "Economic Growth and Social Capital in Italy," Eastern Economic Journal 21, 295-307.

Heston, A., R. Summers, and B. Aten. (2002). "Penn World Tables, Version 6.1," Center for International Comparisons (CICUP), University of Pennsylvania. Inglehart, R., M. Basañez, J. Díez-Medrano, L. Halman, and R. Luijkx. (2004). Human Beliefs and Values. Ann Arbor: University of Michigan Press.

Jacobs, J. (1961). The Death and Life of Great American Cities. New York: Random House.

Kaufmann, D., A. Kraay, and M. Mastruzzi. (2003). “Governance Matters III: Governance Indicators for 1996-2002”, World Bank Policy Research Working Paper no. 3106 . 
Knack, S. (2001). “Trust, Associational Life and Economic Performance.” In John F. Helliwell (ed), The Contribution of Human and Social Capital to Sustained Economic Growth and Well-Being. Quebec: Human Resources Development Canada.

Knack, S. (2002). "Social Capital and the Quality of Government: Evidence from the US States," American Journal of Political Science 46, 772-785.

Knack, S., and P. Keefer. (1995). "Institutions and Economic Performance: CrossCountry Tests using Alternative Institutional Measures," Economics and Politics 7, 207227.

Knack, S., and P. Keefer. (1997). "Does Social Capital have an Economic Pay-Off? A Cross-Country Investigation,” Quarterly Journal of Economics 112, 1251-1288.

Knack, S., and P.J. Zak. (2002). "Building Trust: Public Policy, Interpersonal Trust, and Economic Development," Supreme Court Economic Review 10, 91-107.

Kormendi, R.C., and P.G. Meguire. (1985). "Macroeconomic Determinants of Growth: Cross-Country Evidence," Journal of Monetary Economics 16, 141-163.

Kumlin, S., and B. Rothstein (forthcoming). "Making and Breaking Social Capital: The Impact of Welfare State Institutions," Forthcoming in Comparative Political Studies. La Porta, R., F. Lopez-de-Silanes, A. Shleifer, and R.W. Vishny. (1997). “Trust in Large Organizations," American Economic Review 87, 333-338.

Levine, R., and D. Renelt. (1992). “A Sensitivity Analysis of Cross-Country Growth Regressions," American Economic Review 82, 942-963.

Lorgelly, P.K., and P.D. Owen. (1999). "The Effect of Female and Male Schooling on Economic Growth in the Barro-Lee Model,” Empirical Economics 24, 537-557. Loury, G. (1977). “A Dynamic Theory of Racial Income Differences.” In Phyllis Wallace and Anette M. LaMond (eds), Women, Minorities, and Employment. Lexington, MA: Lexington Books.

Luhman, N. (1979). Trust and Power. New York: John Wiley.

Lynn, R., and T. Vanhanen. (2002). IQ and the Wealth of Nations. Westport, CT: Greenwood Press.

Mauro, P. (1995). "Corruption and Growth,” Quarterly Journal of Economics 110, 681712.

Méon, P-G., and L. Weill. (2005). "Does Better Governance Foster Efficiency? An Aggregate Frontier Analysis," Economics of Governance 6, 75-90. 
Nelson, R.R., and E.S. Phelps. (1966). "Investment in Humans, Technological

Diffusion, and Economic Growth," American Economic Review 56, p. 69-75.

Pritchett, L. (2001). "Where Has All the Education Gone?” World Bank Economic

Review 15, 367-391.

Putnam, R. (1993). Making Democracy Work. Civic Traditions in Modern Italy.

Princeton, NJ: Princeton University Press.

Putnam, R. (2000). Bowling Alone. The Collapse and Revival of American

Community. New York: Simon \& Schuster.

Putnam, R. (2001). “Social Capital: Measurement and Consequences,” ISUMA 2, 41 51 .

Rice, T.W., and A. Sumberg. (1997). "Civic Culture and Democracy in the American States," Publius 23, 99-114.

Rodrik, D., A. Sumbramanian, and F. Trebbi. (2004). "Institutions Rule: the Primacy of Institutions Over Geography and Integration in Economic Development,“ Journal of Economic Growth 9, 131-165.

Romer, P. (1990). “Endogenous Technological Change,” Journal of Political Economy 98, S71-S102.

Rothstein, B. (2003). "Social Capital, Economic Growth and Quality of Government," New Political Economy 8, 49-72.

Staiger, D., and J.H. Stock. (1997). "Instrumental Variables Regression with Weak Instruments," Econometrica 65, 557-86.

Stolle, D. (1998). "Bowling Together, Bowling Alone: the Development of Generalized Trust in Voluntary Associations," Political Psychology 14, 497-525.

Svendsen, G.T. (2004). “The Bumblebee in Economics. Can Social Capital Help Explaining the Welfare State?" Mimeo, University of Aarhus.

Temple, J. (2001). "Generalizations that aren't? Evidence on education and growth,” European Economic Review 45, 905-918.

Topel, R. (1999). “Labor Markets and Economic Growth.” In Orley C. Ashenfelter and David Card (eds), Handbook of Labor Economics, Vol. 3C. Amsterdam: NorthHolland.

USDS. (2004). International Religious Freedom Report 2004. Washington, DC: United States Department of State. 
Uslaner, E.M. (2002). The Moral Foundations of Trust. Cambridge, UK: Cambridge University Press.

Volken, T. (2002) “Generalisiertes Vertrauen: Zur Reliabilität und Validität eines verbreiteten Messinstruments in Wirtschaftssoziologisches

Forschungszusammenhängen.” Mimeo, University of Zürich.

Wacziarg, R. (2001). "Measuring the Dynamic Gains to Trade," World Bank Economic Review 15, 393-429.

Weede, E., and S. Kämpf. (2002). ”The Impact of Intelligence and Institutional Improvement on Economic Growth," Kyklos 55, 361-380.

Whiteley, P. (2000). “Economic Growth and Social Capital,” Political Studies 48, 443466.

World Bank. (2004). World Development Indicators. Washington DC: the World Bank. Zak, P.J., and S. Knack. (2001). "Trust and Growth,” The Economic Journal 111, 295321.

Zelner, A and H. Theil. (1962). "Simultaneous Estimation of Simultaneous Equations," Econometrica 30, 54-78. 
Table 1

Descriptive statistics

\begin{tabular}{lccc}
\hline Variable & Mean & Standard deviation & Observations \\
\hline Economic growth & 1.724 & 1.637 & 73 \\
Ethnic diversity & .367 & .233 & 80 \\
Fertility & .3051 & 1.498 & 80 \\
Governance & .449 & .958 & 74 \\
Government effectiveness & .498 & 1.0318 & 79 \\
Government expenditure & 17.974 & 8.477 & 79 \\
Income inequality & 39.68 & 10.64 & 80 \\
Investment rate & 18.326 & 2.927 & 74 \\
Legal quality & 6.358 & 2.031 & 74 \\
Log initial GDP per capita & 8.4946 & .8590 & 79 \\
Monarchy & .177 & .384 & 80 \\
Openness & 61.608 & 42.874 & 71 \\
Population growth & 1.645 & .999 & 69 \\
Postcommunist & .177 & .384 & 60 \\
Price distortion & 1.349 & .575 & 79 \\
Rule of law & .448 & 1.040 & 64 \\
Schooling & .050 & 1.568 & 80 \\
Share of Buddhists & 3.723 & 17.454 & 80 \\
Share of Hindi & 1.377 & 9.313 & 80 \\
Share of Muslims & 8.09 & 22.00 & 80 \\
Share of Protestants & 17.56 & 28.33 & 80 \\
Social trust & 28.128 & 14.789 & \\
& & & 9 \\
\hline
\end{tabular}


Table 2

Correlations with social trust

\begin{tabular}{lccc}
\hline & Simple correlation & Partial correlation & Observations \\
\hline Schooling & .609 & $.432^{* * *}$ & 65 \\
Rule of law & .676 & $.513^{* * *}$ & 72 \\
Investment rate & .472 & $.211^{*}$ & 72 \\
Price distortion & -.368 & -.055 & 69 \\
Openness & .077 & -.128 & 72 \\
Government expenditure & -.348 & -.149 & 72 \\
Governance & .653 & $.468^{* * *}$ & 72 \\
Legal quality & .594 & $.438^{* * *}$ & 69 \\
\hline
\end{tabular}

Note: $* * *(* *)[*]$ denotes significance at $\mathrm{p}<.01(\mathrm{p}<.05)[\mathrm{p}<.10]$. Partial correlations are controlled for initial GDP per capita. 
Table 3

Determinants of social trust

\begin{tabular}{|c|c|c|c|c|c|c|}
\hline \multirow{3}{*}{$\begin{array}{l}\text { Dependent variable } \\
\text { Estimation method }\end{array}$} & \multicolumn{6}{|c|}{ Social trust } \\
\hline & OLS & OLS & OLS & 2SLS & 2SLS & 2SLS \\
\hline & 1 & 2 & 3 & 4 & 5 & 6 \\
\hline \multirow[t]{2}{*}{ Income inequality } & $-.5882 * * *$ & $-.5069 * * *$ & $-.6255^{* * *}$ & $-.5161 * * *$ & $-.5204 * *$ & $-.4359 *$ \\
\hline & $(.1126)$ & $(.1331)$ & $(.1188)$ & $(.1557)$ & $(.2047)$ & $(.2289)$ \\
\hline \multirow[t]{2}{*}{ Postcommunist } & $-7.9050 * * *$ & $-7.0034 * *$ & $-11.5044 * * *$ & $-12.5819 * * *$ & -7.0611 & -5.9823 \\
\hline & $(2.7073)$ & $(3.0181)$ & $(3.3834)$ & $(3.2267)$ & $(4.2733)$ & $(5.2255)$ \\
\hline \multirow[t]{2}{*}{ Protestants } & $.1396^{* *}$ & $.1341 * *$ & $.1225 *$ & $.1011^{*}$ & $.1354 * *$ & $.1328 * *$ \\
\hline & $(.0561)$ & $(.0552)$ & $(.0645)$ & $(.0592)$ & $(.0671)$ & $(.0557)$ \\
\hline \multirow[t]{2}{*}{ Muslims } & $-.0963 * * *$ & $-.0948 * * *$ & $-.0898 * *$ & $-.0825 * * *$ & -.0701 & $-.0895 * *$ \\
\hline & $(.0362)$ & $(.0339)$ & $(.0386)$ & $(.0343)$ & $(.0539)$ & $(.0342)$ \\
\hline \multirow[t]{2}{*}{ Monarchy } & $10.0360 * * *$ & $9.8889 * * *$ & $11.9468 * * *$ & $10.5339 * * *$ & $9.8335 * * *$ & $10.6132 * * *$ \\
\hline & $(3.3943)$ & $(3.3279)$ & $(3.7595)$ & $(3.5330)$ & $(3.2539)$ & $(3.7142)$ \\
\hline Ethnic diversity & & $\begin{array}{l}-8.8419 \\
(5.7572)\end{array}$ & & & & \\
\hline Schooling & & & & $\begin{array}{c}1.4411 \\
(1.2464)\end{array}$ & & \\
\hline Rule of law & & & & & $\begin{array}{l}1.1752 \\
(3.1505)\end{array}$ & \\
\hline Government expenditure & & & & & & $\begin{array}{l}-.5150 \\
(.6079)\end{array}$ \\
\hline Observations & 82 & 81 & 64 & 64 & 71 & 71 \\
\hline Pseudo R squared & .495 & .505 & .536 & .553 & .511 & .485 \\
\hline F-statistic & 14.70 & 15.78 & 13.47 & 14.55 & 11.82 & 12.45 \\
\hline RMSE & 9.6929 & 9.6014 & 9.9554 & 9.8285 & 9.9933 & 10.251 \\
\hline Sargan test, $\mathrm{p}<$ & & & & .3788 & .3316 & .3432 \\
\hline
\end{tabular}

Note: robust standard errors in parenthesis; ${ }^{* * *}(* *)[*]$ denotes significance at $\mathrm{p}<.01(\mathrm{p}<.05)$ [p<.10]. Instruments for schooling in column four are the log to GDP per capita 1970 and the average fertility rate; for governance in column five the log to GDP per capita 1970, openness and a dummy for common law systems; and for government expenditure in column six the log to GDP per capita 1970. 
Table 4

Direct consequences of social trust

\begin{tabular}{|c|c|c|c|c|c|c|}
\hline \multirow{4}{*}{$\begin{array}{l}\text { Dependent variable } \\
\text { Estimation method } \\
\text { Sample }\end{array}$} & \multicolumn{3}{|c|}{ Schooling } & \multicolumn{3}{|c|}{ Rule of law } \\
\hline & 2SLS & 2SLS & 2SLS & 2SLS & 2SLS & 2SLS \\
\hline & Full & Reduced & No outliers & Full & Reduced & No outliers \\
\hline & 1 & 2 & 3 & 4 & 5 & 6 \\
\hline \multirow[t]{2}{*}{ Log GDP per capita 1970} & $.6415^{* * *}$ & $.5954 * *$ & $.7467 * *$ & $.4953 * * *$ & $.4371 * *$ & $.5231 * * *$ \\
\hline & $(.2351)$ & $(.2628)$ & $(.2861)$ & $(.1439)$ & $(.1652)$ & $(.1023)$ \\
\hline \multirow[t]{2}{*}{ Fertility } & $-.5064 * * *$ & $-.5274 * * *$ & $-.4754 * *$ & & & \\
\hline & $(.1521)$ & $(.1899)$ & $(.1860)$ & & & \\
\hline \multirow[t]{2}{*}{ Openness } & & & & $.0051 * * *$ & $.0054 * * *$ & $.0046 * * *$ \\
\hline & & & & $(.0014)$ & $(.0015)$ & $(.0011)$ \\
\hline \multirow[t]{2}{*}{ Social trust } & $.0451 * * *$ & $.0401 * * *$ & $.0571^{*}$ & $.0319 * *$ & $.0314 * *$ & $.0219 * * *$ \\
\hline & $(.0141)$ & $(.0137)$ & $(.0295)$ & $(.0127)$ & $(.0131)$ & $(.0069)$ \\
\hline \multirow[t]{2}{*}{ Postcommunist } & $.5814^{*}$ & .4967 & .6969 & -.4484 & -.4931 & $-.4113^{*}$ \\
\hline & $(.3372)$ & $(.3884)$ & $(.4725)$ & $(.2915)$ & $(.3296)$ & $(.2067)$ \\
\hline Observations & 65 & 56 & 56 & 72 & 63 & 63 \\
\hline Pseudo R squared & .827 & .827 & .695 & .753 & .702 & .880 \\
\hline F statistic & 45.68 & 40.81 & 19.07 & 37.47 & 31.33 & 80.45 \\
\hline RMSE & .6673 & .6764 & .7503 & .5533 & .5766 & .3402 \\
\hline Sargan test, $\mathrm{p}<$ & .7662 & .5462 & .7039 & .2646 & .2346 & .3140 \\
\hline
\end{tabular}

Note: robust standard errors in parenthesis; $* * *(* *)[*]$ denotes significance at $\mathrm{p}<.01(\mathrm{p}<.05)[\mathrm{p}<.10]$. All regressions contain regional effects and a constant term. The first stage regression for social trust corresponds to that in Table 3, column 3. Due to problems of overidentification in column 6 , instrumental variables also include the shares of Buddhists and Hindi in the population. 
Table 5

Direct consequences to trust - no effects

\begin{tabular}{|c|c|c|c|c|c|c|}
\hline \multirow{4}{*}{$\begin{array}{l}\text { Dependent variable } \\
\text { Estimation method } \\
\text { Sample }\end{array}$} & \multicolumn{3}{|c|}{ Price distortion } & \multicolumn{3}{|c|}{ Government share of GDP } \\
\hline & 2SLS & 2SLS & 2SLS & 2SLS & 2SLS & 2SLS \\
\hline & Full & Reduced & No outliers & Full & Reduced & No outliers \\
\hline & 1 & 2 & 3 & 3 & 4 & 5 \\
\hline \multirow[t]{2}{*}{ Log GDP per capita 1970} & $-.3628 * * *$ & $-.3364 * * *$ & $-.3153 * * *$ & $-3.8699 * *$ & $-3.5215 * *$ & $-3.5609 * * *$ \\
\hline & $(.1234)$ & $(.0627)$ & $(.0418)$ & $(1.5346)$ & $(1.7186)$ & $(1.0249)$ \\
\hline \multirow[t]{2}{*}{ Openness } & .0001 & .0008 & -.0002 & .0202 & .0199 & .0054 \\
\hline & $(.0008)$ & $(.0008)$ & $(.0005)$ & $(.0203)$ & $(.0227)$ & $(.0110)$ \\
\hline \multirow[t]{2}{*}{ Social trust } & .0011 & .0097 & .0015 & .0681 & -.0238 & .1064 \\
\hline & $(.0057)$ & $(.0069)$ & $(.0026)$ & $(.1700)$ & $(.1808)$ & $(.1256)$ \\
\hline \multirow[t]{2}{*}{ Postcommunist } & .2111 & $.3287 * *$ & .1172 & 1.6099 & .6684 & 3.448 \\
\hline & $(.1810)$ & $(.1514)$ & $(.1057)$ & $(4.3094)$ & $(4.1653)$ & $(2.611)$ \\
\hline Observations & 67 & 57 & 57 & 70 & 60 & 60 \\
\hline Pseudo R squared & .489 & .593 & .797 & .158 & .112 & .430 \\
\hline F statistic & 12.29 & 13.50 & 32.07 & 4.15 & 2.90 & 12.80 \\
\hline RMSE & .4178 & .3154 & .1772 & 7.1074 & 7.4322 & 4.2563 \\
\hline Sargan test, $\mathrm{p}<$ & .6154 & .2041 & .3844 & .2870 & .2885 & .1451 \\
\hline
\end{tabular}

Note: robust standard errors in parenthesis; $* * *(* *)[*]$ denotes significance at $\mathrm{p}<.01(\mathrm{p}<.05)[\mathrm{p}<.10]$. All regressions contain regional effects and a constant term. The first stage regression for social trust corresponds to that in Table 3 , column 3 . 
Table 6

Investments and growth 1970-2000

\begin{tabular}{|c|c|c|c|c|c|c|}
\hline \multirow{4}{*}{$\begin{array}{l}\text { Dependent variable } \\
\text { Estimation method } \\
\text { Sample }\end{array}$} & \multicolumn{3}{|c|}{ Investment rate } & \multicolumn{3}{|c|}{ Growth rate } \\
\hline & 3SLS & 3SLS & 3SLS & $3 \mathrm{SLS}$ & 3SLS & 3SLS \\
\hline & Full & Reduced & No outliers & Full & Reduced & No outliers \\
\hline & 1 & 2 & 3 & 4 & 5 & 6 \\
\hline \multirow[t]{2}{*}{ Log GDP per capita } & $-4.1079 * * *$ & $-4.9717 * * *$ & $-4.5551 * * *$ & $-1.6610 * * *$ & $-1.5102 * * *$ & $-1.8204 * * *$ \\
\hline & $(1.0755)$ & $(1.1216)$ & $(1.0872)$ & $(.3545)$ & $(.3319)$ & $(.4499)$ \\
\hline \multirow[t]{2}{*}{ Openness } & $.0347 * *$ & $.0277 *$ & $.0449 * * *$ & -.0018 & .0008 & -.0051 \\
\hline & $(.0161)$ & $(.0167)$ & $(.0159)$ & $(.0051)$ & $(.0051)$ & $(.0061)$ \\
\hline Price distortion & $\begin{array}{c}-4.7584 * * * \\
(1.0739)\end{array}$ & $\begin{array}{c}-5.2179 * * * \\
(1.1039)\end{array}$ & $\begin{array}{c}-6.8708 * * * \\
(1.2885)\end{array}$ & & & \\
\hline \multirow[t]{2}{*}{ Schooling } & $4.2879 * * *$ & $4.0409 * * *$ & $4.5931 * * *$ & -.0257 & .1077 & -.2991 \\
\hline & $(1.1923)$ & $(1.1851)$ & $(1.1172)$ & $(.3840)$ & $(.3781)$ & $(.4558)$ \\
\hline \multirow[t]{2}{*}{ Government expenditure } & -.0912 & -.1016 & -.0995 & -.0233 & -.0233 & -.0319 \\
\hline & $(.0634)$ & $(.0634)$ & $(.0619)$ & $(.0209)$ & $(.0188)$ & $(.0311)$ \\
\hline \multirow[t]{2}{*}{ Rule of law } & -.8298 & -.1137 & -1.3973 & $1.0212 * * *$ & $.9166^{* *}$ & $1.5557 * * *$ \\
\hline & $(1.4215)$ & $(1.4613)$ & $(1.3490)$ & $(.3603)$ & $(.3817)$ & $(.4834)$ \\
\hline \multirow[t]{2}{*}{ Investment rate } & & & & $.1388 * *$ & $.1123 * *$ & $.1380 * *$ \\
\hline & & & & $(.0549)$ & $(.0499)$ & $(.0593)$ \\
\hline Observations & 63 & 54 & 54 & 63 & 54 & 54 \\
\hline Pseudo R squared & .738 & .765 & .764 & .453 & .557 & .216 \\
\hline Chi squared & 192.52 & 183.75 & 200.73 & 74.12 & 71.05 & 46.35 \\
\hline RMSE & 3.3322 & 3.2444 & 3.2279 & 1.0596 & .9173 & 1.1926 \\
\hline
\end{tabular}

Note: robust standard errors in parenthesis; ${ }^{* * *}(* *)[*]$ denotes significance at $\mathrm{p}<.01(\mathrm{p}<.05)[\mathrm{p}<.10]$. 
Table 7

Summary of transmission channels, cumulative effects

\begin{tabular}{lcccc}
\hline Effect on: & Schooling & Rule of law & Investment rate & Growth rate \\
\hline Full sample & .67 & .47 & 2.86 & .88 \\
& $(43 \%)$ & $(45 \%)$ & $(98 \%)$ & $(54 \%)$ \\
Reduced sample & .59 & .46 & 2.40 & .69 \\
& $(38 \%)$ & $(45 \%)$ & $(82 \%)$ & $(42 \%)$ \\
No outliers & .84 & .32 & 3.88 & 1.04 \\
& $(54 \%)$ & $(31 \%)$ & $(133 \%)$ & $(63 \%)$ \\
\hline
\end{tabular}

Note: numbers are effects of a one standard deviation shock to social trust; numbers in parentheses are effects as percent of a standard deviation of the dependent variable. 
Table A.1

Countries and social trust data

\begin{tabular}{|c|c|c|c|}
\hline Country & Trust & Country & Trust \\
\hline Albania & 25.7 & Latvia & 20.3 \\
\hline Algeria & 11.2 & Lithuania & 25.9 \\
\hline Argentina & 20.8 & Luxembourg & 25.9 \\
\hline Armenia & 24.7 & Macedonia & 10.9 \\
\hline Australia & 43.8 & Malaysia & $10.3^{\mathrm{D}}$ \\
\hline Austria & 32.8 & Malta & 20.7 \\
\hline Azerbaijan & 20.5 & Mexico & 25.1 \\
\hline Bangladesh & 22.2 & Moldova & 18.4 \\
\hline Belarus & 30.5 & Morocco & 23.5 \\
\hline Belgium & 31.4 & Netherlands & 53.9 \\
\hline Bolivia & $17^{\mathrm{L}}$ & New Zealand & 49.0 \\
\hline Brazil & 4.8 & Nicaragua & $20^{\mathrm{L}}$ \\
\hline Bulgaria & 28.6 & Nigeria & 22.7 \\
\hline Canada & 46.9 & Norway & 63.9 \\
\hline Chile & 22.5 & Pakistan & 25.7 \\
\hline Colombia & 10.8 & Panama & $25^{\mathrm{L}}$ \\
\hline Costa Rica & $7.4^{\mathrm{D}}$ & Paraguay & $23^{\mathrm{L}}$ \\
\hline Croatia & 21.0 & Peru & 7.8 \\
\hline Czech Republic & 27.5 & Philippines & 6.9 \\
\hline Denmark & 60.1 & Poland & 23.7 \\
\hline Dominican Republic & 26.4 & Portugal & 15.7 \\
\hline Ecuador & $8.9^{\mathrm{D}}$ & Romania & 14.9 \\
\hline Egypt & 37.9 & Russia & 28.4 \\
\hline El Salvador & $14.6^{\mathrm{D}}$ & Singapore & 16.9 \\
\hline Estonia & 23.9 & Slovakia & 21.9 \\
\hline Finland & 56.4 & Slovenia & 18.2 \\
\hline France & 23.3 & South Africa & 22.2 \\
\hline Georgia & 18.7 & South Korea & 32.5 \\
\hline Germany & 36.1 & Spain & 33.6 \\
\hline Ghana & 22.4 & Sweden & 62.3 \\
\hline Greece & 23.7 & Switzerland & 42.1 \\
\hline Guatemala & $28^{\mathrm{L}}$ & Taiwan & 38.2 \\
\hline Honduras & $25^{\mathrm{L}}$ & Tanzania & 8.1 \\
\hline Hong Kong & $26.8^{\mathrm{D}}$ & Thailand & $38.9^{\mathrm{D}}$ \\
\hline Hungary & 25.9 & Turkey & 10.4 \\
\hline Iceland & 41.5 & Uganda & 7.6 \\
\hline India & 38.3 & Ukraine & 29.1 \\
\hline Indonesia & 51.6 & United Kingdom & 36.9 \\
\hline Ireland & 41.2 & Uruguay & 22.1 \\
\hline Israel & 23.5 & USA & 42.1 \\
\hline Italy & 31.4 & Venezuela & 14.8 \\
\hline Japan & 42.9 & Vietnam & 41.3 \\
\hline Jordan & 27.7 & Zimbabwe & 11.9 \\
\hline
\end{tabular}

Note: observations marked ${ }^{\mathrm{L}}$ derive from the 1995 Latinobarometro; observations marked ${ }^{\mathrm{D}}$ derive from the 2003-2004 Danish social capital project. All other data are averages of all available observations in the World Values Survey. 
Table A.2

Trust results - alternative indicators

\begin{tabular}{|c|c|c|c|c|c|c|}
\hline Dependent variable & IQ & Schooling length & Secondary enrolment & Governance & Legal quality & $\begin{array}{l}\text { Government } \\
\text { effectivenes }\end{array}$ \\
\hline \multirow[t]{2}{*}{ Estimation method } & $2 \mathrm{SLS}$ & $2 \mathrm{SLS}$ & $2 \mathrm{SLS}$ & 2SLS & 2SLS & 2SLS \\
\hline & 1 & 2 & 3 & 4 & 5 & 6 \\
\hline \multirow[t]{2}{*}{ Log GDP per capita 1970} & $2.2194^{*}$ & $1.3720 * *$ & $9.6729^{*}$ & $.4201 * * *$ & $.9099 * * *$ & $.5051 * * *$ \\
\hline & $(1.3043)$ & $(.5511)$ & $(5.6851)$ & $(.1452)$ & $(.3102)$ & $(.1376)$ \\
\hline \multirow[t]{2}{*}{ Fertility } & $-3.3519 * * *$ & -.4396 & -6.3278 & & & \\
\hline & $(.8143)$ & $(.3489)$ & $(4.4658)$ & & & \\
\hline \multirow[t]{2}{*}{ Openness to trade } & & & & $.0048 * * *$ & $.0062 *$ & $.0054 * * *$ \\
\hline & & & & $(.0014)$ & $(.0035)$ & $(.0015)$ \\
\hline \multirow[t]{2}{*}{ Social trust } & .0355 & $.0605 * *$ & $1.133 * *$ & $.0314 * *$ & $.0519^{*}$ & $.0276 * *$ \\
\hline & $(.0613)$ & $(.0284)$ & $(.5014)$ & $(.0126)$ & $(.0314)$ & $(.0112)$ \\
\hline \multirow[t]{2}{*}{ Postcommunist } & -.8378 & 1.6039 & 4.611 & -.2578 & -.6819 & $-.5851 * *$ \\
\hline & $(1.6199)$ & $(.9861)$ & $(9.3793)$ & $(.2779)$ & $(.5999)$ & $(.2343)$ \\
\hline Observations & 77 & 64 & 74 & 70 & 69 & 70 \\
\hline Pseudo R squared & .851 & .676 & .596 & .689 & .634 & .749 \\
\hline F statistic & 49.55 & 32.28 & 24.85 & 32.83 & 18.86 & 39.05 \\
\hline RMSE & 3.668 & 1.3875 & 18.791 & .519 & 1.2502 & .5197 \\
\hline Sargan test, $\mathrm{p}<$ & .1696 & .6782 & .3233 & .5180 & .8018 & .7574 \\
\hline
\end{tabular}

Note: robust standard errors in parenthesis; ${ }^{* * *}(* *)[*]$ denotes significance at $\mathrm{p}<.01(\mathrm{p}<.05)[\mathrm{p}<.10]$. All regressions contain regional effects and a constant term. The first stage regression for social trust in columns 3 and 4 corresponds to that in Table 3, column 3. Instruments for governance and legal quality in columns 1 and 2 are the log to GDP per capita 1970, openness and a dummy for common law systems. All results are obtained using the full sample. 
Table A.3

Economic growth 1970-2000, alternative governance indicators

\begin{tabular}{|c|c|c|c|c|c|c|}
\hline \multirow{3}{*}{$\begin{array}{l}\text { Dependent variable } \\
\text { Estimation method }\end{array}$} & \multicolumn{3}{|c|}{ Investment rate } & \multicolumn{3}{|c|}{ Growth rate } \\
\hline & 3SLS & 3SLS & 3SLS & 3SLS & 3SLS & 3SLS \\
\hline & 1 & 2 & 3 & 4 & 5 & 6 \\
\hline \multirow[t]{2}{*}{ Log GDP per capita } & $-3.2971 * * *$ & $-3.0294 * * *$ & $-3.4637 * * *$ & $-1.7489 * * *$ & $-1.8286^{* * *}$ & $-1.7789 * * *$ \\
\hline & $(1.0249)$ & $(1.0397)$ & $(1.0363)$ & $(.3884)$ & $(.3834)$ & $(.3499)$ \\
\hline \multirow[t]{2}{*}{ Openness } & $.0291 * *$ & $.0331 * *$ & $.0256^{*}$ & -.0009 & -.0028 & -.0001 \\
\hline & $(.0145)$ & $(.0152)$ & $(.0151)$ & $(.0056)$ & $(.0057)$ & $(.0049)$ \\
\hline \multirow[t]{2}{*}{ Price distortion } & $-5.3759 * * *$ & $-4.9887 * * *$ & $-5.1213 * * *$ & & & \\
\hline & $(1.0683)$ & $(1.0893)$ & $(1.0858)$ & & & \\
\hline \multirow[t]{2}{*}{ Schooling } & $2.7942 * * *$ & $4.0402 * * *$ & $3.5148 * * *$ & -.0037 & -.1450 & .2261 \\
\hline & $(.8856)$ & $(.9892)$ & $(.8524)$ & $(.4621)$ & $(.4654)$ & $(.3494)$ \\
\hline \multirow[t]{2}{*}{ Government expenditure } & -.1046 & -.07001 & -.0782 & -.0271 & -.0141 & -.0179 \\
\hline & $(.0688)$ & $(.0641)$ & $(.0639)$ & $(.0244)$ & $(.0225)$ & $(.0204)$ \\
\hline \multirow[t]{2}{*}{ Legal quality } & .2203 & & & $.4250 * *$ & & \\
\hline & $(.5830)$ & & & $(.2031)$ & & \\
\hline \multirow[t]{2}{*}{ Governance } & & -1.6886 & & & $1.3524 * *$ & \\
\hline & & $(1.4814)$ & & & $(.5401)$ & \\
\hline \multirow[t]{2}{*}{ Government effectiveness } & & & .0081 & & & $.7927 * *$ \\
\hline & & & $(1.0833)$ & & & $(.3242)$ \\
\hline \multirow[t]{2}{*}{ Investment rate } & & & & $.1793 * * *$ & $.1749 * * *$ & $.1293 * *$ \\
\hline & & & & $(.0638)$ & $(.0632)$ & $(.0557)$ \\
\hline Observations & 63 & 63 & 63 & 63 & 63 & 63 \\
\hline Pseudo R squared & .752 & .727 & .739 & .296 & .346 & .483 \\
\hline Chi squared & 185.96 & 174.79 & 181.30 & 60.82 & 63.26 & 69.86 \\
\hline RMSE & 3.2142 & 3.3701 & 3.2939 & 1.2029 & 1.1593 & 1.0302 \\
\hline
\end{tabular}

Note: robust standard errors in parenthesis; $*^{* *}(* *)[*]$ denotes significance at $\mathrm{p}<.01(\mathrm{p}<.05)[\mathrm{p}<.10]$. All results are obtained using the full sample. 
Department of Economics:

Skriftserie/Working Paper:

2002:

WP 02-1 Peter Jensen, Michael Rosholm and Mette Verner: A Comparison of Different Estimators for Panel Data Sample Selection Models. ISSN 1397-4831.

WP 02-2 Erik Strøjer Madsen, Camilla Jensen and Jørgen Drud Hansen: Scale in Technology and Learning-by-doing in the Windmill Industry. ISSN 1397-4831.

WP 02-3 Peter Markussen, Gert Tinggaard Svendsen and Morten Vesterdal: The political economy of a tradable GHG permit market in the European Union. ISSN 13974831.

WP 02-4 Anders Frederiksen og Jan V. Hansen: Skattereformer: Dynamiske effekter og fordelingskonsekvenser. ISSN 1397-4831.

WP 02-5 Anders Poulsen: On the Evolutionary Stability of Bargaining Inefficiency. ISSN 1397-4831.

WP 02-6 Jan Bentzen and Valdemar Smith: What does California have in common with Finland, Norway and Sweden? ISSN 1397-4831.

WP 02-7 Odile Poulsen: Optimal Patent Policies: A Survey. ISSN 1397-4831.

WP 02-8 Jan Bentzen and Valdemar Smith: An empirical analysis of the interrelations among the export of red wine from France, Italy and Spain. ISSN 1397-4831.

WP 02-9 A. Goenka and O. Poulsen: Indeterminacy and Labor Augmenting Externalities. ISSN 1397-4831.

WP 02-10 Charlotte Christiansen and Helena Skyt Nielsen: The Educational Asset Market: A Finance Perspective on Human Capital Investment. ISSN 1397-4831.

WP 02-11 Gert Tinggaard Svendsen and Morten Vesterdal: CO2 trade and market power in the EU electricity sector. ISSN 1397-4831.

WP 02-12 Tibor Neugebauer, Anders Poulsen and Arthur Schram: Fairness and Reciprocity in the Hawk-Dove game. ISSN 1397-4831.

WP 02-13 Yoshifumi Ueda and Gert Tinggaard Svendsen: How to Solve the Tragedy of the Commons? Social Entrepreneurs and Global Public Goods. ISSN 1397-4831.

WP 02-14 Jan Bentzen and Valdemar Smith: An empirical analysis of the effect of labour market characteristics on marital dissolution rates. ISSN 1397-4831. 
WP 02-15 Christian Bjørnskov and Gert Tinggaard Svendsen: Why Does the Northern Light Shine So Brightly? Decentralisation, social capital and the economy. ISSN 13974831.

WP 02-16 Gert Tinggaard Svendsen: Lobbyism and $\mathrm{CO}_{2}$ trade in the EU. ISSN 1397-4831.

WP 02-17 Søren Harck: Reallønsaspirationer, fejlkorrektion og reallønskurver. ISSN 13974831.

WP 02-18 Anders Poulsen and Odile Poulsen: Materialism, Reciprocity and Altruism in the Prisoner’s Dilemma - An Evolutionary Analysis. ISSN 1397-4831.

WP 02-19 Helena Skyt Nielsen, Marianne Simonsen and Mette Verner: Does the Gap in Family-friendly Policies Drive the Family Gap? ISSN 1397-4831.

2003:

WP 03-1 Søren Harck: Er der nu en strukturelt bestemt langsigts-ledighed I SMEC?: Phillipskurven i SMEC 99 vis-à-vis SMEC 94. ISSN 1397-4831.

WP 03-2 Beatrice Schindler Rangvid: Evaluating Private School Quality in Denmark. ISSN 1397-4831.

WP 03-3 Tor Eriksson: Managerial Pay and Executive Turnover in the Czech and Slovak Republics. ISSN 1397-4831.

WP 03-4 Michael Svarer and Mette Verner: Do Children Stabilize Marriages? ISSN 13974831.

WP 03-5 Christian Bjørnskov and Gert Tinggaard Svendsen: Measuring social capital - Is there a single underlying explanation? ISSN 1397-4831.

WP 03-6 Vibeke Jakobsen and Nina Smith: The educational attainment of the children of the Danish 'guest worker’ immigrants. ISSN 1397-4831.

WP 03-7 Anders Poulsen: The Survival and Welfare Implications of Altruism When Preferences are Endogenous. ISSN 1397-4831.

WP 03-8 Helena Skyt Nielsen and Mette Verner: Why are Well-educated Women not Fulltimers? ISSN 1397-4831.

WP 03-9 Anders Poulsen: On Efficiency, Tie-Breaking Rules and Role Assignment Procedures in Evolutionary Bargaining. ISSN 1397-4831.

WP 03-10 Anders Poulsen and Gert Tinggaard Svendsen: Rise and Decline of Social Capital - Excess Co-operation in the One-Shot Prisoner's Dilemma Game. ISSN 13974831. 
WP 03-11 Nabanita Datta Gupta and Amaresh Dubey: Poverty and Fertility: An Instrumental Variables Analysis on Indian Micro Data. ISSN 1397-4831.

WP 03-12 Tor Eriksson: The Managerial Power Impact on Compensation - Some Further Evidence. ISSN 1397-4831.

WP 03-13 Christian Bjørnskov: Corruption and Social Capital. ISSN 1397-4831.

WP 03-14 Debashish Bhattacherjee: The Effects of Group Incentives in an Indian Firm - Evidence from Payroll Data. ISSN 1397-4831.

WP 03-15 Tor Eriksson och Peter Jensen: Tidsbegränsade anställninger - danska erfarenheter. ISSN 1397-4831.

WP 03-16 Tom Coupé, Valérie Smeets and Frédéric Warzynski: Incentives, Sorting and Productivity along the Career: Evidence from a Sample of Top Economists. ISSN 1397-4831.

WP 03-17 Jozef Koning, Patrick Van Cayseele and Frédéric Warzynski: The Effects of Privatization and Competitive Pressure on Firms' Price-Cost Margins: Micro Evidence from Emerging Economies. ISSN 1397-4831.

WP 03-18 Urs Steiner Brandt and Gert Tinggaard Svendsen: The coalition of industrialists and environmentalists in the climate change issue. ISSN 1397-4831.

WP 03-19 Jan Bentzen: An empirical analysis of gasoline price convergence for 20 OECD countries. ISSN 1397-4831.

WP 03-20 Jan Bentzen and Valdemar Smith: Regional income convergence in the Scandinavian countries. ISSN 1397-4831.

WP 03-21 Gert Tinggaard Svendsen: Social Capital, Corruption and Economic Growth: Eastern and Western Europe. ISSN 1397-4831.

WP 03-22 Jan Bentzen and Valdemar Smith: A Comparative Study of Wine Auction Prices: Mouton Rothschild Premier Cru Classé. ISSN 1397-4831.

WP 03-23 Peter Guldager: Folkepensionisternes incitamenter til at arbejde. ISSN 1397-4831.

WP 03-24 Valérie Smeets and Frédéric Warzynski: Job Creation, Job Destruction and Voting Behavior in Poland. ISSN 1397-4831.

WP 03-25 Tom Coupé, Valérie Smeets and Frédéric Warzynski: Incentives in Economic Departments: Testing Tournaments? ISSN 1397-4831.

WP 03-26 Erik Strøjer Madsen, Valdemar Smith and Mogens Dilling-Hansen: Industrial clusters, firm location and productivity - Some empirical evidence for Danish firms. ISSN 1397-4831. 
WP 03-27 Aycan Çelikaksoy, Helena Skyt Nielsen and Mette Verner: Marriage Migration: Just another case of positive assortative matching? ISSN 1397-4831.

2004:

WP 04-1 Elina Pylkkänen and Nina Smith: Career Interruptions due to Parental Leave - A Comparative Study of Denmark and Sweden. ISSN 1397-4831.

WP 04-2 Urs Steiner Brandt and Gert Tinggaard Svendsen: Switch Point and First-Mover Advantage: The Case of the Wind Turbine Industry. ISSN 1397-4831.

WP 04-3 Tor Eriksson and Jaime Ortega: The Adoption of Job Rotation: Testing the Theories. ISSN 1397-4831.

WP 04-4 Valérie Smeets: Are There Fast Tracks in Economic Departments? Evidence from a Sample of Top Economists. ISSN 1397-4831.

WP 04-5 Karsten Bjerring Olsen, Rikke Ibsen and Niels Westergaard-Nielsen: Does Outsourcing Create Unemployment? The Case of the Danish Textile and Clothing Industry. ISSN 1397-4831.

WP 04-6 Tor Eriksson and Johan Moritz Kuhn: Firm Spin-offs in Denmark 1981-2000 Patterns of Entry and Exit. ISSN 1397-4831.

WP 04-7 Mona Larsen and Nabanita Datta Gupta: The Impact of Health on Individual Retirement Plans: a Panel Analysis comparing Self-reported versus Diagnostic Measures. ISSN 1397-4831.

WP 04-8 Christian Bjørnskov: Inequality, Tolerance, and Growth. ISSN 1397-4831.

WP 04-9 Christian Bjørnskov: Legal Quality, Inequality, and Tolerance. ISSN 1397-4831.

WP 04-10 Karsten Bjerring Olsen: Economic Cooperation and Social Identity: Towards a Model of Economic Cross-Cultural Integration. ISSN 1397-4831.

WP 04-11 Iben Bolvig: Within- and between-firm mobility in the low-wage labour market. ISSN 1397-4831.

WP 04-12 Odile Poulsen and Gert Tinggaard Svendsen: Social Capital and Market Centralisation: A Two-Sector Model. ISSN 1397-4831.

WP 04-13 Aditya Goenka and Odile Poulsen: Factor Intensity Reversal and Ergodic Chaos. ISSN 1397-4831.

WP 04-14 Jan Bentzen and Valdemar Smith: Short-run and long-run relationships in the consumption of alcohol in the Scandinavian countries.

ISBN 87-7882-010-3 (print); ISBN 87-7882-011-1 (online). 
WP 04-15 Jan Bentzen, Erik Strøjer Madsen, Valdemar Smith and Mogens Dilling-Hansen: Persistence in Corporate Performance? Empirical Evidence from Panel Unit Root Tests.

ISBN 87-7882-012-X (print); ISBN 87-7882-013-8 (online).

WP 04-16 Anders U. Poulsen and Jonathan H.W. Tan: Can Information Backfire? Experimental Evidence from the Ultimatum Game.

ISBN 87-7882-014-6 (print); ISBN 87-7882-015-4 (online).

WP 04-17 Werner Roeger and Frédéric Warzynski: A Joint Estimation of Price-Cost Margins and Sunk Capital: Theory and Evidence from the European Electricity Industry.

ISBN 87-7882-016-2 (print); ISBN 87-7882-017-0 (online).

WP 04-18 Nabanita Datta Gupta and Tor Eriksson: New workplace practices and the gender wage gap.

ISBN 87-7882-018-9 (print); ISBN 87-7882-019-7 (online).

WP 04-19 Tor Eriksson and Axel Werwatz: The Prevalence of Internal Labour Markets New Evidence from Panel Data.

ISBN 87-7882-020-0 (print); ISBN 87-7882-021-9 (online).

WP 04-20 Anna Piil Damm and Michael Rosholm: Employment Effects of Dispersal Policies on Refugee Immigrants: Empirical Evidence.

ISBN 87-7882-022-7 (print); ISBN 87-7882-023-5 (online).

2005:

WP 05-1 Anna Piil Damm and Michael Rosholm: Employment Effects of Dispersal Policies on Refugee Immigrants: Theory.

ISBN 87-7882-024-3 (print); ISBN 87-7882-025-1 (online).

WP 05-2 Anna Piil Damm: Immigrants' Location Preferences: Exploiting a Natural Experiment.

ISBN 87-7882-036-7 (print); ISBN 87-7882-037-5 (online).

WP 05-3 Anna Piil Damm: The Danish Dispersal Policy on Refugee Immigrants 1986-1998: A Natural Experiment?

ISBN 87-7882-038-3 (print); ISBN 87-7882-039-1 (online).

WP 05-4 Rikke Ibsen and Niels Westergaard-Nielsen: Job Creation and Destruction over the Business Cycles and the Impact on Individual Job Flows in Denmark 1980-2001. ISBN 87-7882-040-5 (print); ISBN 87-7882-041-3 (online).

WP 05-5 Anna Maria Kossowska, Nina Smith, Valdemar Smith and Mette Verner: Til gavn for bundlinjen - Forbedrer kvinder i topledelse og bestyrelse danske virksomheders bundlinje?

ISBN 87-7882-042-1 (print); ISBN 87-7882-043-X (online). 
WP 05-6 Odile Poulsen and Gert Tinggaard Svendsen: The Long and Winding Road: Social Capital and Commuting.

ISBN 87-7882-044-8 (print); ISBN 87-7882-045-6 (online).

WP 05-7 Odile Poulsen and Gert Tinggaard Svendsen: Love Thy Neighbor: Bonding versus Bridging Trust.

ISBN 87-7882-062-6 (print); ISBN 87-7882-063-4 (online).

WP 05-8 Christian Bjørnskov: Political Ideology and Economic Freedom.

ISBN 87-7882-064-2 (print); ISBN 87-7882-065-0 (online).

WP 05-9 Sebastian Buhai and Coen Teulings: Tenure Profiles and Efficient Separation in a Stochastic Productivity Model.

ISBN 87-7882-066-9 (print); ISBN 87-7882-067-7 (online).

WP 05-10 Christian Grund and Niels Westergård-Nielsen: Age Structure of the Workforce and Firm Performance.

ISBN 87-7882-068-5 (print); ISBN 87-7882-069-3 (online).

WP 05-11 Søren Harck: AD-AS på dansk.

ISBN 87-7882-070-7 (print); ISBN 87-7882-071-5 (online).

WP 05-12 Søren Harck: Hviler Dansk Økonomi på en Cobb-Douglas teknologi? ISBN 87-7882-092-8 (print); ISBN 87-7882-093-6 (online).

2006:

WP 06-1 Nicolai Kristensen and Edvard Johansson: New Evidence on Cross-Country Differences in Job Satisfaction Using Anchoring Vignettes.

ISBN 87-7882-094-4 (print); ISBN 87-7882-095-2 (online).

WP 06-2 Christian Bjørnskov: How Does Social Trust Affect Economic Growth? ISBN 87-7882-096-0 (print); ISBN 87-7882-097-9 (online). 